\title{
The Effects of Celebrity Endorsement on Customer's Attitude toward Brand and Purchase Intention
}

\author{
Nguyen Minh $\mathrm{Ha}^{1} \&$ Nguyen Hung Lam ${ }^{1}$ \\ ${ }^{1}$ Graduate School, Ho Chi Minh City Open University, Vietnam \\ Correspondence: Nguyen Minh Ha, Graduate School, Ho Chi Minh City Open University, 97 Vo Van Tan Street, \\ District 3, Ho Chi Minh City, Vietnam. Tel: 84-8-3930-0947. E-mail: ha.nm@ou.edu.vn or \\ ngmiha2014@gmail.com
}

Received: July 9, 2016

Accepted: July 29, 2016

Online Published: December 14, 2016

doi:10.5539/ijef.v9n1p64

URL: http://dx.doi.org/10.5539/ijef.v9n1p64

\begin{abstract}
Celebrity endorsement has become a popular choice in advertising due to the its originality and the celebrity's attractiveness that make a big impact on brand awareness and customer behavior. This study analyzes the effect of celebrity endorsement on customer's attitude toward brand as well as the effect of customer's attitude toward brand on customer's purchase intention in Vietnam. A survey was conducted with 306 individuals in Vietnam. After conducting the explanatory factor analysis (EFA), and multi-variable regression analysis, results indicate that customer's attitude toward brand is positively affected by 03 factors: celebrity match-up congruence with the brand/product, celebrity trustworthiness, and celebrity expertise. Attitude toward brand also has a positive impact on customer's purchase intention.
\end{abstract}

Keywords: celebrity endorsement, customer's attitude toward brand, purchase intention

\section{Introduction}

In recent years, the development of commercial communication and of rise-up of live TV shows has attracted lots of attention from the public, especially young generation. Marketing strategies of companies focus mostly on promoting products to the market with core objectives as to persuade their customers; since the customers have got a lot of knowledge, references, and choices before making a purchase decision, competition has also became more severely. There are a number of ways to promote brands, but employing celebrity as an aid to the brand has become popular in all over the world (Friedman et al., 1979; Kamins, 1989). This is because advertisements in which celebrity appears are generating effective outcomes in making the brand identity and retaining customers' attention, that is the mandatory objective of any commerce (Erdogan, 1999; Kamins \& Gupta, 1994; Kaikati, 1987; Patti \& Frazer, 1988). Belch and Belch (2004, p. 174) showed that "in today's television viewing environment and the "stopping power" of celebrity endorsed commercials are more remarkable". However, if they later make up a negative image of themselves, brand image will also be affected. Therefore, it is very important to select appropriate celebrity to represent a brand.

There have been a lot of studies in the world on the effect of celebrity on brand promotion activities, but this field hasn't been addressed adequately in Vietnam. The questions are that which factors of celebrity endorsement will have effect on customer's attitude toward brand and how is the relationship between customer's attitude toward brand and purchase intention in Vietnam?

\section{Literature Review}

There are a lot of definitions of celebrity. According to Young and Pinsky (2006, p. 464) "individuals who have achieved a significant level of fame that makes them well known in society". The celebrity has rose to become a powerful force in the 21st century and hold an important role in the contemporary culture (Koernig \& Boyd, 2009; Lord \& Putrevu, 2009). A celebrity is a person whose name can attract public attention, ignite public interest, and create individual values from the public (Kotler, Keller, \& Jha, 2007). However, perhaps the most impressive and widely referenced definition is Daniel Boorstin's (1982, p. 49), in which he defined: as "The celebrity is a person who is known for his well-knownness".

Early definition of celebrity endorsement is mentioned by Freiden (1984). According to him, celebrity endorsement means celebrity in direct connection to an advertised product. According to McCracken (1989, p. 
310): "An individual who enjoys public recognition and who uses this recognition on behalf of a customer good by appearing with it in an advertisement". According to Kotler et al. (2007), celebrity endorsement is one of communication channels that are used by celebrity as a means of expressing their words to promote the brand on basis of their fame and personalities.

\subsection{Meaning Transfer Model}

According to McCracken (1989), this model is developed to illustrate celebrity endorsement process. Advertising is one of means to transfer individual meaning to the brands. This model is divided into three stages. First stage is the development of celebrity image and description of cultural meaning of the society. In this stage, it is assessed whether subject, people and context are suitable to the celebrity. The second stage is relevant to the celebrity's transfer of meanings from brand endorsement to the product. In the final stage, brand image is transferred to the customers.
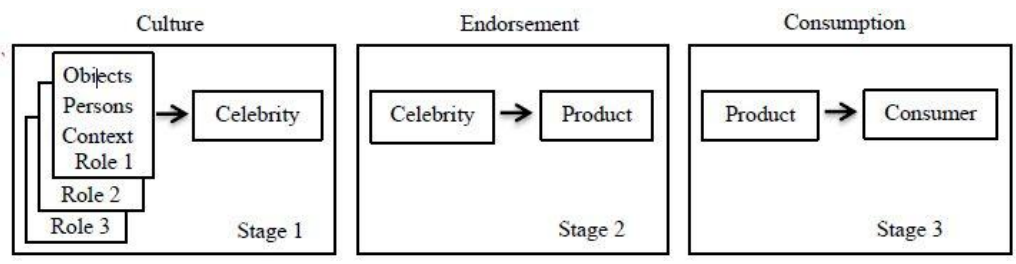

Figure 1. Meaning transfer model

Note. $\rightarrow$ Path of meaning movement.

Source: McCracken, 1989, p. 45.

\subsection{Customer's Attitude Toward Brand}

Customer's attitude toward brand is predisposition that focuses on favorable or unfavorable impact on a specific brand after watching an advertisement on that brand (Phelps \& Hoy, 1996). According to Lutz et al. (1983), customer's attitude toward brand is the customer's emotional reaction toward a brand advertisement. It is associated with the customer's feeling if his/her purchase intention toward the brand is positive or negative, favorable or unfavorable.

\subsection{The Elaboration Likelihood Model (ELM)}

Elaboration Likelihood Model (ELM) is a model that consists of two phases of response toward advertising incentive. It explains how attitudes are formed on basis of the degree of participation. Current attitude may be changed and it is assumed that when a customer receives a message, he starts processing it. There are two possible directions: Central route used for persuasion if customer participation is high, or peripheral route used for persuasion if customer participation is low. The model has two fundamental factors, motivation and ability to process communication. Motivation means the customer's readiness, participation, and needs. Ability means the knowledge, qualification, and capacity to process information (Petty et al., 1983).

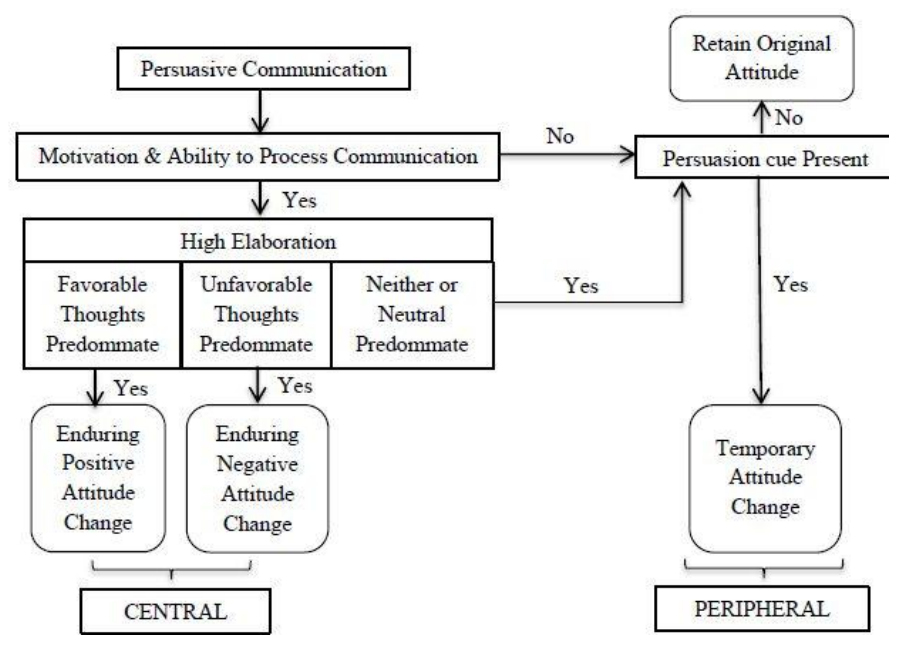

Source: Petty et al., 1983.

Figure 2. Elaboration Likelihood Model (ELM) 


\subsection{The Relation between Source Credibility Model and Customer's Attitude toward Brand}

Hovland \& Weiss (1953) introduced a source credibility model, which is further studied by Ohanian (1990) (cited by Armando, 2014). According to source credibility model, "the effectiveness of a message depends on the apparent level of expertise and trustworthiness of the endorser" (Hovland \& Weiss, 1953, p. 20)

\subsubsection{Celebrity Trustworthiness}

Trustworthiness refers to "the honesty, integrity and believability of an endorser" (Erdogan et al., 2001, p. 40). A celebrity is considered as trustworthy (Goldsmith et al., 2000) and his/her trustworthiness is described as a summary of values that create positive features and increase the acceptance of the message (Erdogan, 1999). Trustworthiness is the most useful and effective tool to make the customer be more confident and reliable on the brand (Ohanian, 1990). A hypothesis is provided:

Hypothesis 1 (H1): The more celebrity trustworthiness is perceived by the customer, the more positive customer's attitude toward brand will be.

\subsubsection{Celebrity Expertise}

Hovland et al. (1953) defines expertise as the level of knowledge and experience that a person may obtain in a specific field that is acknowledged as valid. The more persuasive a celebrity's expertise is (Aaker, 1997), the more purchase decisions will be generated (Ohanian, 1991). Speck, Schumann, and Thompson (1988) affirms that celebrity is considered as an expert in a specific field, resulting in a higher brand endorsement than a celebrity without expertise (Hoekman \& Bosmans, 2010). Following hypothesis is provided:

Hypothesis 2 (H2): The more celebrity expertise is perceived by the customer, the more positive customer's attitude toward brand will be.

\subsection{The Relation between Source Attractiveness Model and Customer's Attitude toward Brand}

Source attractiveness model is developed by McGuire (1985), he holds that an individual message is accepted and affected by the similarity between the receiver and the sender together with the familiarity and likeliness. The meaning of source attractiveness model is referenced to be a famous philosopher, Aristotle: "beauty is a greater recommendation than any letter of introduction". Aristotle wants to emphasize that the most importance is beauty and attractiveness (Hoekman \& Bosmans, 2010).

\subsubsection{Celebrity Attractiveness}

Physical attractiveness transited via a person's weight, height, and facial beauty is the very first expressions perceived by another (Bardia et al., 2011). This concept does not only means physical attractiveness. It also requires mental skills, personality, lifestyle, and art talents (Erdogan, 1999). A celebrity is attractive because he/she has built up a popular image among the public. His/her attractiveness increases the persuasiveness toward the customers as they want to be like the celebrity that they love (Cohen \& Golden, 1972). A hypothesis is given

Hypothesis 3 (H3): The more celebrity attractiveness is perceived by the customer, the more positive customer's attitude toward brand will be.

\subsubsection{Celebrity Similarity}

Similarity is described as "a supposed resemblance between the source and the receiver of the message" (McGuire, 1985). In other words, a customer may similarize himself with the endorser. People will be more easily influenced when they find the similarity between them and the endorser. If the celebrity and the customers share popular factors, such as similar interest or lifestyle, a better association will be formed (Erdogan, 1999). Following hypothesis is provided:

Hypothesis 4 (H4): The more celebrity similarity is perceived by the customer, the more positive customer's attitude toward brand will be.

\subsubsection{Celebrity Liking}

Likeability is the "affection for the source as a result of the source's physical appearance and behaviour" (McGuire, 1985, p. 239). In addition, McGuire also holds that when customers like a celebrity, they will like brands associated with the celebrity. A hypothesis is provided:

Hypothesis 5 (H5): The more celebrity liking is perceived by the customer, the more positive customer's attitude toward brand will be.

\subsubsection{Celebrity Familiarity}

Familiarity means the feeling of similarity by means of emotions and contact with a celebrity (Erdogan, 1999; 
Belch \& Belch, 2004). Celebrity familiarity will have a more positive impact when the customer himself finds that he/she is similar to the celebrity. This is called the mere exposure effect (Zajonc, 1968). When the customers have short contacts with the celebrity and contact interval becomes longer, the effects of familiarity will improve customer's attitude toward brand. On the contrary, the effect is negative when they have long contacts and contact interval becomes shorter (Bornstein, 1989). A hypothesis is given by:

Hypothesis 6 (H6): The more celebrity familiarity is perceived by the customer, the more positive customer's attitude toward brand will be.

\subsection{The Relationship between Brand/Product Match - up Hypothesis Model and Customer's Attitude toward} Brand

According to Forkan (1980); Kamins (1989), brand/product match - up hypothesis model means that celebrity image and product message must be similar and matched up in order for the advertisement to be effective.

\subsubsection{Celebrity Match-up Congruence With The Brand/Product}

A number of studies conducted by Cooper (1984) and Forkan (1980) indicate that celebrity match-up congruence with the brand/product has a significant play. When a product is advertised by a celebrity with suitable image that is highly relevant to the product, the confidence will be higher on the advertisement and the celebrity compared to a product image promoted by a less famous, less relevant person (Kotler, 1997). A hypothesis is given:

Hypothesis 7 (H7): The more celebrity match-up congruence with the brand/product is perceived by the customer, the more positive customer's attitude toward brand will be.

\subsubsection{The Relationship between Customer's Attitude toward Brand and Purchase Intention}

Customer's purchase intention addresses the predisposition to purchase a certain brand or product (Belch \& Belch, 2004). Purchase intention also tells about the possibility that a person will purchase a product (Phelps \& Hoy, 1996). Amos, et al. (2008) hold that the customer's positive attitude toward celebrity endorsement will improve his/her purchase intention. Many studies also indicate that customer's attitude toward brand has a positive and significant impact on purchase intention (Mitchell \& Olson, 1981; Gresham \& Shimp, 1985; Batra \& Ray, 1986; Phelps \& Hoy, 1996). A hypothesis is provided:

Hypothesis 8 (H8): The more positive customer's attitude toward brand is, the more positive purchase intention will be.

\section{Methodology and Research Model}

\subsection{Methodology}

This study is conducted in two major stages. A qualitative study is conducted by face-to-face direct interview on 04 marketing experts and a group discussion is carried out among 12 customers of 18 years old or more, which is intended to modify, supplement, and complete the measurement scale. A quantitative study is carried out to collect data by using a questionnaire survey based on Likert rating scale with 5 options, including "1-Totally Disagree", "2-Disagree", "3-Neutral", "4-Agree", "5-Totally Agree", used to measure observation variables for each factor.

\subsection{Proposed Research Model}

From theories and previous studies, an analysis is conducted on the effect of the celebrity endorsement consisting of 07 factors, which are: celebrity trustworthiness, celebrity attractiveness, celebrity expertise, celebrity similarity, celebrity liking, celebrity familiarity, celebrity match-up congruence with the brand/product are independent varieties. Customer's attitude toward brand means temporary variable. Purchase intention means dependent variable. 


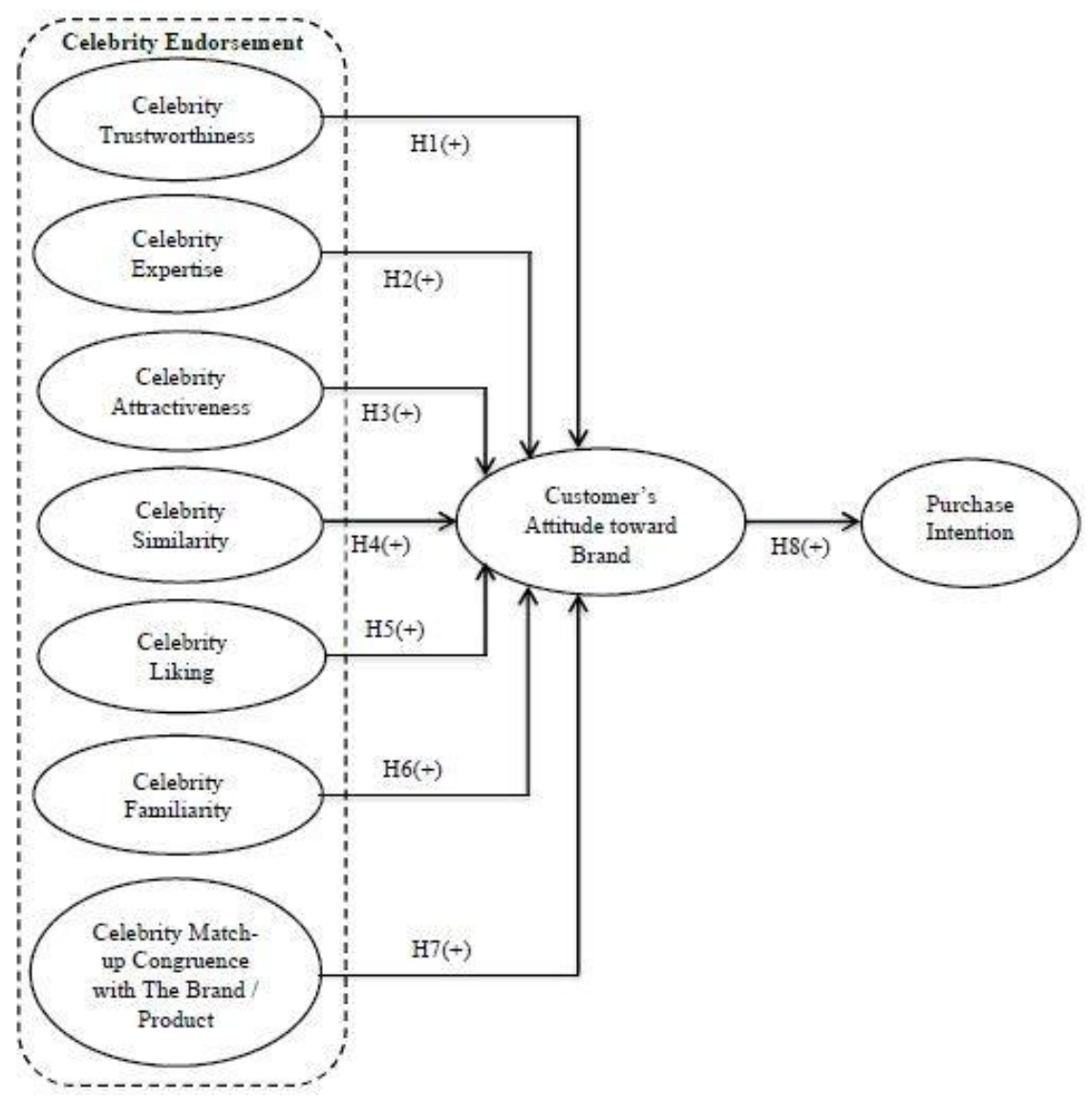

Figure 3. Proposed research model

\subsection{Research Data}

A total of 534 questionnaire sheets were directly distributed to the customers of 18 years old or more in Vietnam or via online method. A total of 392 sheets were returned and, after being screened, 306 sheets were valid for data analysis, achieving a ratio of $78.06 \%$ compared to actual data.

\section{Research Results}

\subsection{Descritptive Statistics by Characteristics}

For gender, there are 184 female and 122 male respondents, accounting for $60.1 \%$ and $39.9 \%$, respectively, of which $61.4 \%$ are single, $38.6 \%$ are married. For age, respondents of $18-25$ years old account for $28.1 \%$, of $26-$ 35 years old account for $58.5 \%, 36-45$ years old account for $7.5 \%$, and of more than 45 years old account for $5.9 \%$. For education, university respondents account for $45.1 \%$, post-graduate ones account for $28.4 \%$, primary school ones account for $2.6 \%$, secondary school ones account for $7.2 \%$, high school ones account for $8.5 \%$, and college-intermediary school ones account for $8.2 \%$.

\subsection{Descriptive Statistics of Model Variables}

Table 1. Descriptive statistic of quantitative variables

\begin{tabular}{|c|c|c|c|c|c|}
\hline & Content & Min & Max & Mean & Standard Deviation \\
\hline \multicolumn{6}{|c|}{ Celebrity Trustworthiness } \\
\hline CT1 & You believe in celebrity's brand choice. & 1 & 5 & 3.15 & 0.904 \\
\hline $\mathrm{CT} 2$ & You think that the celebrity is an honest person. & 1 & 5 & 2.92 & 0.866 \\
\hline CT3 & You think that the celebrity provides reliable source of information. & 1 & 5 & 2.94 & 0.878 \\
\hline CT4 & You think that the celebrity is a sincere person. & 1 & 5 & 2.93 & 0.875 \\
\hline CT5 & You think that the celebrity is a trustworthy person. & 1 & 5 & 2.96 & 0.892 \\
\hline \multicolumn{6}{|c|}{ Celebrity Expertise } \\
\hline CE1 & You think that the celebrity is an expert in the field that he/she represents. & 1 & 5 & 2.60 & 0.964 \\
\hline CE2 & You think that the celebrity has experience in using the brand. & 1 & 5 & 3.02 & 0.887 \\
\hline
\end{tabular}




\begin{tabular}{|c|c|c|c|c|c|}
\hline CE3 & You think that the celebrity has a lot of knowledge about this brand. & 1 & 5 & 2.92 & 0.884 \\
\hline CE4 & You think that the celebrity has got high professional qualification. & 1 & 5 & 2.77 & 0.908 \\
\hline CE5 & You think that the celebrity has skilled this brand. & 1 & 5 & 3.01 & 0.905 \\
\hline \multicolumn{6}{|c|}{ Celebrity Attractiveness } \\
\hline CA1 & You think that the celebrity has got a strong attractiveness. & 1 & 5 & 4.01 & 0.696 \\
\hline CA2 & You think that the celebrity is a very classy. & 1 & 5 & 3.36 & 0.881 \\
\hline CA3 & You think that the celebrity has a very pretty face. & 1 & 5 & 3.81 & 0.831 \\
\hline CA4 & You think that the celebrity has a very elegant fashion style. & 2 & 5 & 3.87 & 0.801 \\
\hline CA5 & You think that the celebrity has a very attractive appearance. & 1 & 5 & 3.82 & 0.864 \\
\hline CA6 & You think that the celebrity has a very persuasive voice. & 1 & 5 & 3.46 & 0.846 \\
\hline CA7 & You think that the celebrity has a very professional manner. & 2 & 5 & 3.81 & 0.778 \\
\hline \multicolumn{6}{|c|}{ Celebrity Similarity } \\
\hline CS1 & You think that the celebrity and you share the same culture. & 1 & 5 & 3.01 & 0.861 \\
\hline $\mathrm{CS} 2$ & You think that the celebrity and you share similar lifestyle. & 1 & 5 & 2.56 & 0.817 \\
\hline $\mathrm{CS} 3$ & You think that the celebrity and you share similar interests. & 1 & 5 & 2.89 & 0.873 \\
\hline CS4 & You think that the celebrity and you share similar perspectives. & 1 & 5 & 2.60 & 0.771 \\
\hline CS5 & You think that the celebrity and you share similar likings. & 1 & 5 & 2.67 & 0.886 \\
\hline \multicolumn{6}{|c|}{ Celebrity Liking } \\
\hline CL1 & You like the celebrity's behaviors. & 1 & 5 & 3.36 & 0.757 \\
\hline CL2 & You like the celebrity's appearance. & 1 & 5 & 3.75 & 0.762 \\
\hline CL3 & You think that the celebrity is very popular. & 1 & 5 & 4.07 & 0.721 \\
\hline CL4 & You like the celebrity's voice. & 1 & 5 & 3.34 & 0.800 \\
\hline CL5 & You like the celebrity's fashion style. & 1 & 5 & 3.64 & 0.818 \\
\hline CL6 & You like the celebrity's professional manner. & 1 & 5 & 3.71 & 0.799 \\
\hline CL7 & Overall, you like the celebrity. & 1 & 5 & 3.66 & 0.806 \\
\hline \multicolumn{6}{|c|}{ Celebrity Familiarity } \\
\hline $\mathrm{CF} 1$ & You often see the celebrity on the TV. & 1 & 5 & 4.15 & 0.625 \\
\hline $\mathrm{CF} 2$ & You often see the celebrity on the stage or in the cinema. & 1 & 5 & 3.31 & 0.950 \\
\hline CF3 & You often see the celebrity at events or festivals. & 1 & 5 & 3.52 & 0.877 \\
\hline CF4 & You often see the celebrity on the advertising boards. & 2 & 5 & 4.06 & 0.627 \\
\hline CF5 & You often see the celebrity on the newspapers. & 1 & 5 & 4.10 & 0.609 \\
\hline CF6 & You often see the celebrity in person. & 1 & 5 & 2.57 & 0.994 \\
\hline CF7 & You often see the celebrity on the Internet. & 1 & 5 & 4.15 & 0.672 \\
\hline CF8 & You often listen to the celebrity over the radio. & 1 & 5 & 3.07 & 0.989 \\
\hline \multicolumn{6}{|c|}{ Celebrity Match-up Congruence with The Brand / Product } \\
\hline CM1 & You often see the celebrity in the advertisements of this brand. & 1 & 5 & 3.93 & 0.694 \\
\hline CM2 & You think that celebrity image suits this brand. & 1 & 5 & 3.74 & 0.736 \\
\hline CM3 & You think that this brand is totally suitable for the celebrity to represent. & 1 & 5 & 3.67 & 0.779 \\
\hline CM4 & You think that the celebrity that represents this brand is trustworthy. & 1 & 5 & 3.43 & 0.787 \\
\hline CM5 & You believe that the celebrity is using this brand. & 1 & 5 & 3.05 & 0.943 \\
\hline \multicolumn{6}{|c|}{ Customer's Attitude toward Brand } \\
\hline $\mathrm{AB} 1$ & You believe that this brand is a good one. & 1 & 5 & 3.54 & 0.724 \\
\hline $\mathrm{AB} 2$ & You think that this brand is very interesting. & 1 & 5 & 3.50 & 0.712 \\
\hline $\mathrm{AB} 3$ & You like this brand. & 1 & 5 & 3.44 & 0.763 \\
\hline $\mathrm{AB} 4$ & You think that this brand has a good quality. & 2 & 5 & 3.46 & 0.751 \\
\hline AB5 & You are satisfied with this brand. & 1 & 5 & 3.46 & 0.734 \\
\hline AB6 & You are confident in this brand. & 1 & 5 & 3.42 & 0.766 \\
\hline \multicolumn{6}{|c|}{ Purchase Intention } \\
\hline PI1 & You will seek more information on this product. & 1 & 5 & 3.59 & 0.806 \\
\hline PI2 & You will actively seek for this product. & 1 & 5 & 3.41 & 0.857 \\
\hline $\mathrm{PI} 3$ & You will try this product when you see it. & 1 & 5 & 3.68 & 0.762 \\
\hline PI4 & You will purchase this product. & 1 & 5 & 3.34 & 0.823 \\
\hline PI5 & $\begin{array}{l}\text { Celebrity appearance in the advertisement has motivated you to purchase } \\
\text { this product. }\end{array}$ & 1 & 5 & 3.21 & 1.009 \\
\hline
\end{tabular}

Celebrity trustworthiness: CT1 has the highest mean value (3.15), while CT2 has the lowest mean value (2.92). So, the customers are confident on celebrity's brand choice, but they don't think that the celebrity is honest.

Celebrity expertise: CE2 has the highest mean value (3.02), while CE1 has the lowest mean value (2.60). Hence, the customers think that the celebrity has a lot of experience in using this brand, but they don't think that the celebrity is an expert in the field that he/she represents. 
Celebrity attractiveness: CA1 has the highest mean value (4.01), while CA2 has the lowest mean value (3.36). Hence, the customers think that the celebrity has got a strong attractiveness, but they don't think that the celebrity is a very skilled elite.

Celebrity similarity: CS1 has the highest mean value (3.01), while CS2 has the lowest mean value (2.56). Hence, the customers think that the celebrity and they share the same culture, but they don't think that the celebrity and them share similar lifestyle.

Celebrity liking: CL3 has the highest mean value (4.07), while CL4 has the lowest mean value (3.34). Hence, the customers think that the celebrity is very popular, but they don't like his/her voice.

Celebrity familiarity: CF1 and CF7 has the highest mean value (4.15), while CF6 has the lowest mean value (2.57). Hence, the customers agree that they often see the celebrity on the TV and Internet, but they don't agree that they often see the celebrity in person.

Celebrity match-up congruence with the brand / product: CM1 has the highest mean value (3.93), while has the lowest mean value (3.05). Hence, the customers often see the celebrity in brand advertisements, but they don't believe that the celebrity is using this product.

Customer's attitude toward brand: AB1 has the highest mean value (3.54), while AB6 has the lowest mean value (3.42). Hence, the customers believe that the brand represented by the celebrity is a good one, but they don't believe in this brand.

Purchase intention: PI3 has the highest mean value (3.68), while PI5 has the lowest mean value (3.21). Hence, the customers agree that they will try this product when they see it, but they don't think that celebrity appearance in the advertisement has motivated them to purchase the product.

\subsection{Testing the Cronbach's Alpha}

Celebrity trustworthiness: Removing CT1 has the Cronbach's Alpha if item deleted is 0.908 larger than the Cronbach's Alpha coefficient of the 1st scale test value of 0.907. In the 2nd test, the Cronbach's Alpha coefficient is 0.908 , and item-total correlation for all variables are satisfied (higher than 0.3). Therefore, remaining 4 observation variables are included in factor analysis (EFA).

Celebrity expertise: The Cronbach's Alpha coefficient is 0.817 , and item-total correlation for all variables are satisfied (higher than 0.3). Therefore, the 5 observation variables are included in EFA.

Celebrity attractiveness: The Cronbach's Alpha coefficient is 0.810 , and item-total correlation for all variables are satisfied (higher than 0.3). Therefore, the 7 observation variables are included in EFA.

Celebrity similarity: removing CS1 has the Cronbach's Alpha if item deleted is 0.867 larger than the Cronbach's Alpha coefficient of the 1st scale test value of 0.851. In the 2nd test, the Cronbach's Alpha coefficient is 0.867, and item-total correlation for all variables are satisfied (higher than 0.3 ). Therefore, remaining 4 observation variables are included in factor analysis (EFA).

Celebrity liking: The Cronbach's Alpha coefficient is 0.833 , and item-total correlation for all variables are satisfied (higher than 0.3). Therefore, the 7 observation variables are included in EFA.

Celebrity familiarity: 3 varieties which are eliminated because the correlation coefficients of item-total is not satisfied (lower than 0.3) include CF1(0.273), CF6 (0.243), and CF8 (0.297). After eliminating such varieties, the Cronbach's Alpha coefficient has been increased. Hence, the 2nd test shall be conducted, the Cronbach's Alpha coefficient is 0.684 , and the item-total correlation for all variables are satisfied (higher than 0.3). Therefore, remaining 5 observation variables are included in EFA.

Celebrity match-up congruence with the brand / product: CM1 and CM5 are eliminated because they have the Cronbach's Alpha if item deleted are 0.787 and 0.801 respectively, and higher than the Cronbach's Alpha coefficient of the 1st test scale of 0.784 . In the 2nd test, CM4 is eliminated because it has the Cronbach's Alpha if item deleted is 0.863 higher than the Cronbach's Alpha coefficient of the 2nd scale test value of 0.822 . In the 3rd test, the Cronbach's Alpha coefficient is 0.863 , and item-total correlation for all variables are satisfied (higher than 0.3). Therefore, remaining 2 observation variables are included in EFA

Customer's attitude toward brand: $\mathrm{AB} 2$ is eliminated because it has the Cronbach's Alpha if item deleted is 0.930, which is higher than the 1st scale test value of 0.923. In the 2nd test, AB1 is eliminated because it has the Cronbach's Alpha if item deleted is 0.931, which is higher than the Cronbach's Alpha coefficient of the 2nd scale test value of 0.930. In the 3rd test, the Cronbach's Alpha coefficient is 0.931, and item-total correlation for all variables are satisfied (higher than 0.3). Therefore, remaining 4 observation variables are included in EFA. 
Purchase intention: PI5 is eliminated because it has the Cronbach's Alpha if item deleted is 0.865 , which is higher than the Cronbach's Alpha coefficient of the 1st scale test value of 0.860. In the 2nd test, the Cronbach's Alpha coefficient is 0.865 , and item-total correlation for all variables are satisfied (higher than 0.3 ). Therefore, remaining 4 observation variables are included in EFA.

Table 2. The Cronbach's Alpha coefficient of the variables in the model

\begin{tabular}{|c|c|c|c|}
\hline Variable & Corrected Item-Total Correlation & Cronbach's Alpha if Item Deleted & Cronbach's Alpha \\
\hline \multicolumn{4}{|c|}{ Celebrity Trustworthiness } \\
\hline СТ2 & 0.803 & 0.877 & \multirow{4}{*}{0.908} \\
\hline CT3 & 0.734 & 0.901 & \\
\hline CT4 & 0.828 & 0.868 & \\
\hline CT5 & 0.803 & 0.877 & \\
\hline \multicolumn{4}{|c|}{ Celebrity Expertise } \\
\hline CE1 & 0.546 & 0.800 & \multirow{5}{*}{0.817} \\
\hline CE2 & 0.612 & 0.779 & \\
\hline CE3 & 0.706 & 0.752 & \\
\hline CE4 & 0.563 & 0.794 & \\
\hline CE5 & 0.616 & 0.778 & \\
\hline \multicolumn{4}{|c|}{ Celebrity Attractiveness } \\
\hline CA1 & 0.462 & 0.798 & \multirow{7}{*}{0.810} \\
\hline CA2 & 0.469 & 0.800 & \\
\hline CA3 & 0.661 & 0.764 & \\
\hline CA4 & 0.656 & 0.765 & \\
\hline CA5 & 0.582 & 0.778 & \\
\hline CA6 & 0.488 & 0.795 & \\
\hline CA7 & 0.513 & 0.790 & \\
\hline \multicolumn{4}{|c|}{ Celebrity Similarity } \\
\hline CS2 & 0.705 & 0.836 & \multirow{4}{*}{0.867} \\
\hline CS3 & 0.696 & 0.840 & \\
\hline CS4 & 0.784 & 0.807 & \\
\hline CS5 & 0.697 & 0.840 & \\
\hline \multicolumn{4}{|c|}{ Celebrity Liking } \\
\hline CL1 & 0.523 & 0.819 & \multirow{7}{*}{0.833} \\
\hline CL2 & 0.578 & 0.811 & \\
\hline CL3 & 0.533 & 0.818 & \\
\hline CL4 & 0.562 & 0.814 & \\
\hline CL5 & 0.602 & 0.807 & \\
\hline CL6 & 0.604 & 0.807 & \\
\hline CL7 & 0.666 & 0.796 & \\
\hline \multicolumn{4}{|c|}{ Celebrity Familiarity } \\
\hline CF2 & 0.389 & 0.671 & \multirow{5}{*}{0.684} \\
\hline $\mathrm{CF} 3$ & 0.430 & 0.641 & \\
\hline CF4 & 0.513 & 0.610 & \\
\hline CF5 & 0.503 & 0.616 & \\
\hline CF7 & 0.436 & 0.636 & \\
\hline \multicolumn{4}{|c|}{ Celebrity Match-up Congruence with The Brand / Product } \\
\hline CM2 & 0.760 & & \multirow{2}{*}{0.863} \\
\hline CM3 & 0.760 & & \\
\hline \multicolumn{4}{|c|}{ Customer's Attitude toward Brand } \\
\hline AB3 & 0.817 & 0.917 & \multirow{4}{*}{0.931} \\
\hline AB4 & 0.814 & 0.918 & \\
\hline AB5 & 0.867 & 0.901 & \\
\hline AB6 & 0.857 & 0.904 & \\
\hline \multicolumn{4}{|c|}{ Purchase Intention } \\
\hline PI1 & 0.733 & 0.820 & \multirow{4}{*}{0.865} \\
\hline PI2 & 0.778 & 0.800 & \\
\hline PI3 & 0.631 & 0.860 & \\
\hline PI4 & 0.719 & 0.826 & \\
\hline
\end{tabular}




\subsection{Explanatory Factor Analysis (EFA)}

Explanatory factor analysis is conducted on whether celebrity endorsement has an impact on customer's attitude toward brand. After the 1st analysis, CA1, CA2, CL1, CL3 CL7, CL2, CL5, CE1, CF4, CL6, CL4 are eliminated. After the 2 nd analysis, CA6, CA7, CE4 are eliminated. After $3^{\text {nd }}$ analysis, CF5 and CF7 are eliminated. After $4^{\text {th }}$ analysis, factor loading values are satisfactory with KMO coefficient of 0.844 with significance level of the Bartlett test of 0.000 .

Table 3. Results of the Explanatory Factor Analysis (EFA)

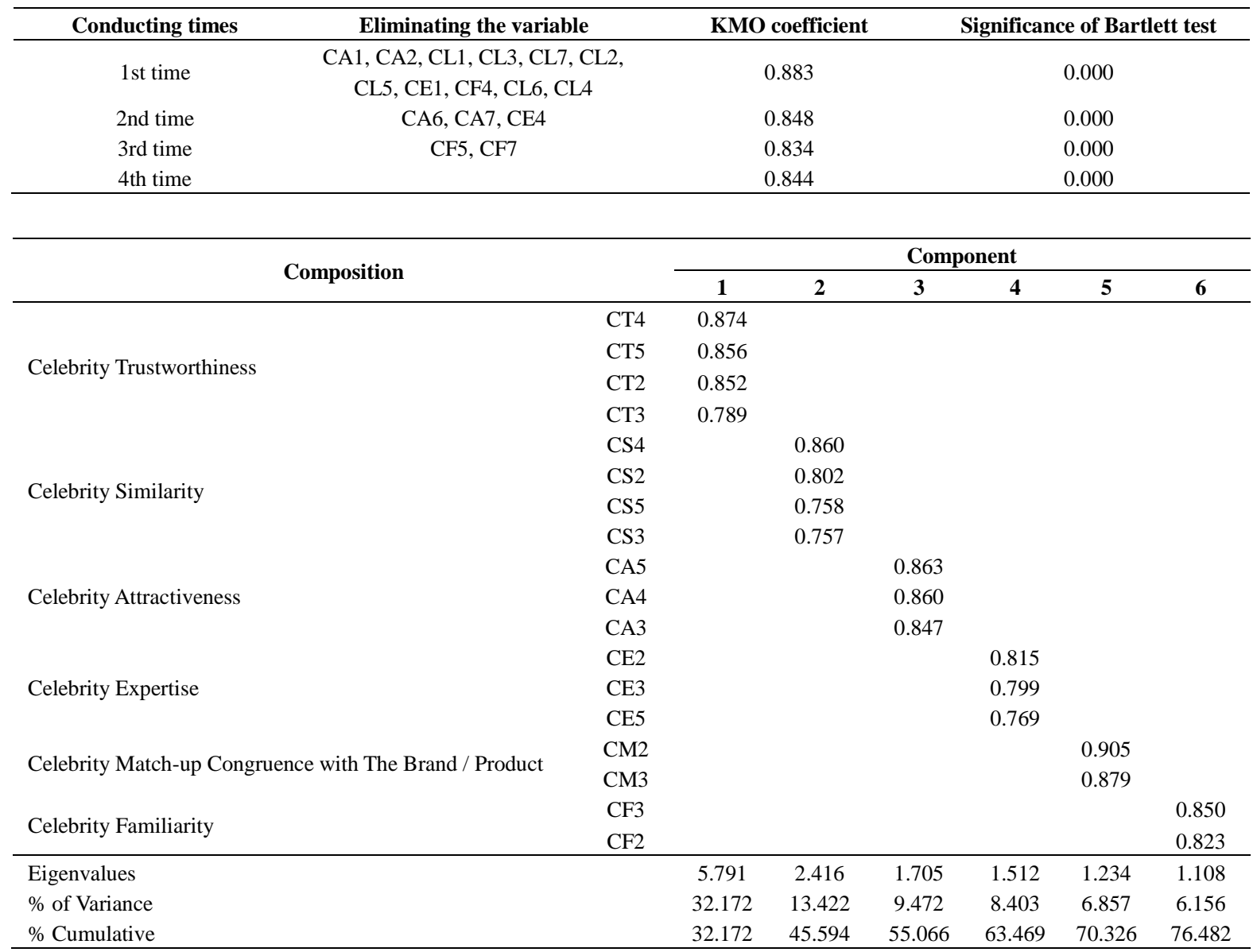

Based on results presented in Table 3,18 observation variables are satisfactory and divided into 6 factor groups. Factors are unchanged from original ones. However, "celebrity liking" factor is eliminated and hypotheses and research model are corrected as follows: 


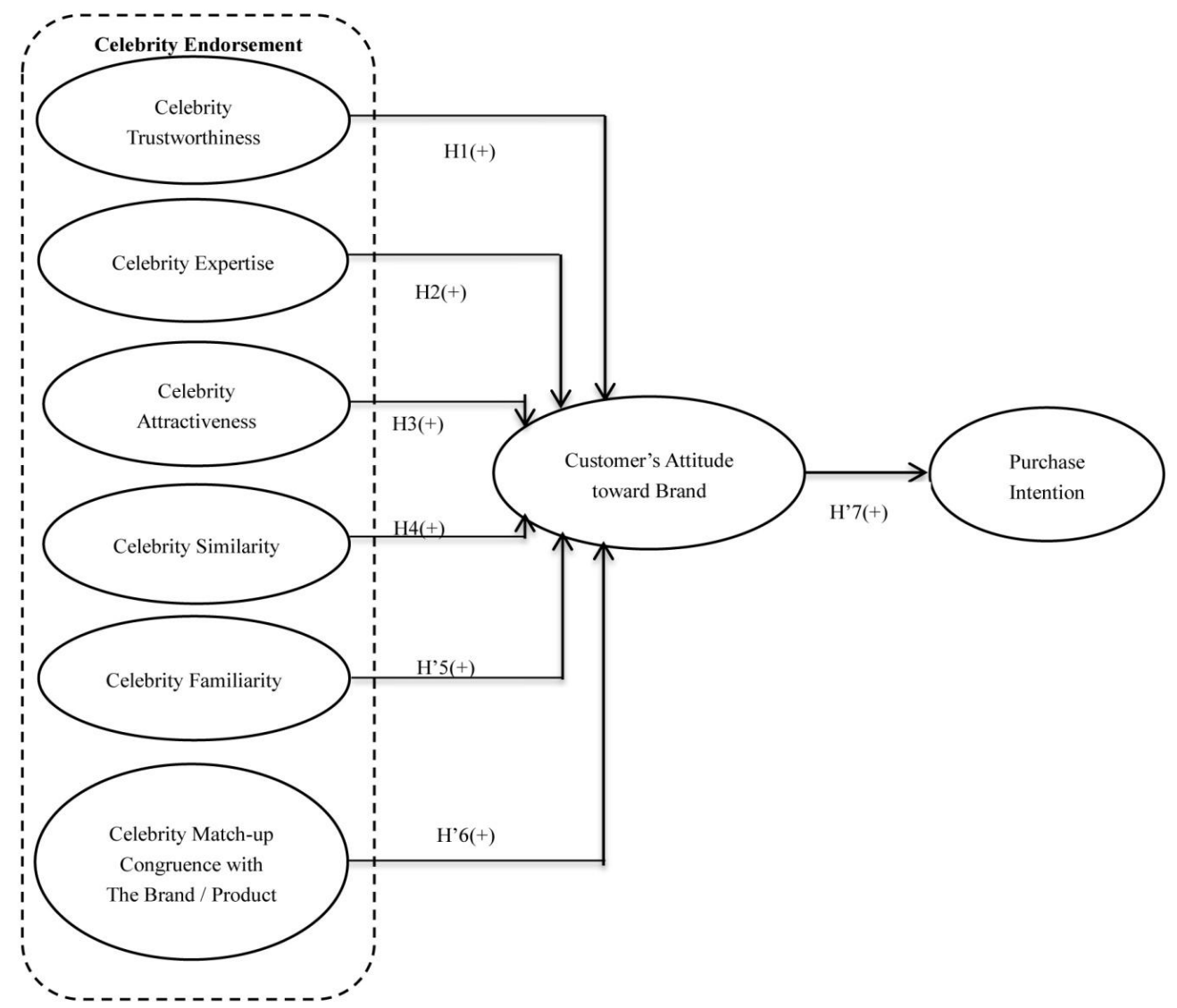

Figure 4. Research model correction

\subsection{Regression Analysis}

According to results in Table 4, Analysis of the fitness of the regression model on customer's attitude toward brand, Adjusted $\mathrm{R}^{2}$ get value is 0.273 , which is varied by $27.3 \%$ in term of "customer's attitude toward brand", it can be explained by independent factors in the model. $\mathrm{F}=20.058$ with significant level of 0.000 . Therefore, the regression model is considered as overall fit.

Table 4. Results of regression analysis the model of customers' attitude towards brand

\begin{tabular}{|c|c|c|c|c|c|}
\hline Model & $\begin{array}{l}\text { Unstandardized } \\
\text { Coefficients (B) }\end{array}$ & $\begin{array}{l}\text { Standardized } \\
\text { Coefficients }(\beta)\end{array}$ & $\mathbf{t}$ & Sig. & VIF \\
\hline (Constant) & 1.126 & & 4.210 & 0.000 & \\
\hline Celebrity Trustworthiness & $0.182 * * *$ & 0.206 & 3.491 & 0.001 & 1.455 \\
\hline Celebrity Expertise & $0.165^{* * *}$ & 0.181 & 3.148 & 0.002 & 1.385 \\
\hline Celebrity Similarity & 0.050 & 0.052 & 0.856 & 0.393 & 1.548 \\
\hline Celebrity Attractiveness & 0.036 & 0.038 & 0.717 & 0.474 & 1.197 \\
\hline Celebrity Match-up Congruence with The Brand/Product & $0.278 * * *$ & 0.288 & 5.223 & 0.000 & 1.275 \\
\hline Celebrity Familiarity & -0.002 & -0.003 & -0.055 & 0.956 & 1.034 \\
\hline $\mathrm{R}$ & 0.536 & & & & \\
\hline $\mathrm{R}^{2}$ & 0.287 & & & & \\
\hline Adjusted $\mathrm{R}^{2}$ & 0.273 & & & & \\
\hline F (Anova) & 20.058 & & & & \\
\hline Sig. (Anova) & 0.000 & & & & \\
\hline Durbin - Watson & 2.069 & & & & \\
\hline
\end{tabular}

Note. Dependent variable: Customer's attitude toward brand. ***: Results at the significance level of $1 \%$.

According to the Table 5, the match-up congruence of the regression model of purchase intention, Adjusted $\mathrm{R}^{2}$ get value is 0.483 , means $48.3 \%$ upon the variability of the purchase intention can be explained by the customers' 
attitude towards brand. $\mathrm{F}=285.814$ with significant level of 0.000 ; therefore, the regression model is considered as overall fit.

Table 5. Results of regression analysis the model of purchase intention

\begin{tabular}{|c|c|c|c|c|c|}
\hline Model & $\begin{array}{l}\text { Unstandardized } \\
\text { Coefficients (B) }\end{array}$ & $\begin{array}{c}\text { Standardized } \\
\text { Coefficients }(\beta)\end{array}$ & $\mathbf{t}$ & Sig. & VIF \\
\hline (Constant) & 1.106 & & 7.646 & 0.000 & \\
\hline Customers' attitude towards brand & $0.696^{* * *}$ & 0.696 & 16.906 & 0.000 & 1.000 \\
\hline $\mathrm{R}$ & 0.696 & & & & \\
\hline $\mathrm{R}^{2}$ & 0.485 & & & & \\
\hline Adjusted $\mathrm{R}^{2}$ & 0.483 & & & & \\
\hline F (Anova) & 285.814 & & & & \\
\hline Sig. (Anova) & 0.000 & & & & \\
\hline Durbin - Watson & 1.973 & & & & \\
\hline
\end{tabular}

Note. Dependent variable: Purchase intention. ***: Results at the significance level of $1 \%$.

\subsection{Discussion of Results}

\subsubsection{Celebrity Trustworthiness}

This variable is statistically significant at $1 \%$, with value $\beta=0.206>0$, this means that $\mathrm{H} 1$ hypothesis is supported. Trustworthiness refers to "the honesty, integrity and believability of an endorser" (Erdogan et al., 2001). The celebrity is considered as a trustworthy person (Goldsmith et al., 2000). A study by Pham \& Nguyen (2015) indicates that "celebrity trustworthiness" has a positive impact on "customer's attitude toward the advertisement". Results of this study also find positive impact of "celebrity trustworthiness" on "customer's attitude toward brand". This can be explained as follows: celebrity appearance in commerces in Vietnam has become popular because the celebrity can influence the public. However, "scandals" in their personal lives have caused the public wonder and lose trusts in the celebrity's ethics. Only a few celebrities are acknowledged for their talents and ethics, and they are respected and relied upon by most of the public and colleagues. Therefore, celebrity endorsement will have more impact on the customers than non-celebrity trustworthy.

\subsubsection{Celebrity Expertise}

This factor is statistically significant at $1 \%$, with value $\beta=0.181>0$, this means that $\mathrm{H} 2$ hypothesis is supported. The expertise mentions the level of knowledge and experience that a person may obtain in a specific field that is acknowledged as valid (Hovland et al., 1953). The more persuasive a celebrity's expertise is (Aaker, 1997), the more purchase decisions will be generated (Ohanian, 1991). A study by Pham and Nguyen (2015) indicates that "celebrity expertise" has a positive impact on "customer's attitude toward the advertisement". Results of this study also find positive impact of "celebrity expertise" on "customer's attitude toward brand". This can be explained as follows: With their attractiveness and influencing ability, celebrities are highly paid for their appearance in advertisements although the brand is not related to their expertises. Therefore, customers feel that they are not assured, and their confidence in the brand is wondered. So, enterprises need to select the celebrities that have expertises related to the brand to be advertised so that customers will be more confident and accept it more positively.

\subsubsection{Celebrity Attractiveness}

This variable is statistically significant at $5 \%$, with value $\beta=0.038$, this means that $\mathrm{H} 3$ hypothesis is not supported. A study by Pham \& Nguyen (2015) indicates that "celebrity attractiveness" has a positive impact on "customer's attitude toward the advertisement". However, this study only considers the "customers' attitude towards brand" and the its results indicate no positive effect of the "celebrity attractiveness" factor on the "customer's attitude toward brand". This can be explained as follows: Most of today's celebrities have pretty, attractive and ideal appearance to make their advertisements more impressive. Therefore, celebrity attractiveness will generate attention toward the customers and make advertisements more attractive, however, attractiveness has no impact on customer's attitude toward brand.

\subsubsection{Celebrity Similarity}

This factor is statistically significant at $5 \%$, with value $\beta=0.052$, this means that $\mathrm{H} 4$ hypothesis is not supported. A study by Pham and Nguyen (2015) indicates that "celebrity similarity" has a positive impact on "customer's attitude toward the advertisement". However, this study only considers the "customers' attitude towards brand" 
and the its results indicate no positive effect of the "celebrity similarity" factor on the "customer's attitude toward brand". This can be explained as follows: Celebrities have ideal appearance and outstanding talents. All fans want to become like the ones that they like, from their lifestyle, likings, fashion style, etc. They learn after celebrities and think that they share similar values, to a certain extent, with celebrities. However, similarity only makes advertisements with celebrity endorsement receive more attention and be remembered, but it does not affect customer's attitude toward brand.

\subsubsection{Celebrity Familiarity}

This variable is statistically significant at $5 \%$, with value $\beta=0.003$, meaning that $\mathrm{H}^{\prime} 5$ hypothesis is not supported. The study by Pham and Nguyen (2015) does not consider "celebrity familiarity" factor. A study by Shahrokh and Arefi (2013) indicates that there is a positive impact of "celebrity familiarity" on "source attractiveness model", and thereby resulting in a positive impact on "the effectiveness of celebrity endorsement". However, this study only considers the "customers' attitude towards brand" and the its results indicate no positive effect of the "celebrity familiarity" factor on the "customer's attitude toward brand". This can be explained as follows: This celebrity will be covered everywhere so that customers can easily see the ones they love just by clicking or navigating a remote control. It is celebrity familiarity that will help the customers easily memorize and be impressed at the advertisements with celebrity endorsement, but familiarity has no impact on customer's attitude toward brand.

\subsubsection{Celebrity Match-up Congruence with The Brand/Product}

This factor is statistically significant at $1 \%$, with value $\beta=0.288>0$, meaning that H'6 hypothesis is not supported. Celebrity match-up congruence with the brand / product may create the absolute confidence through the homogeneous process (Langmeyer \& Walker, 1991), and cause positive effect on the customers' attitude towards advertisment, brand / product and purchase intention (Kirmani \& Shiv, 1998). A study by Pham and Nguyen (2015) indicates that "celebrity match-up congruence with the brand / product" has a positive impact on "customer's attitude toward the advertisement". Results of this study also find positive impact of "celebrity match-up congruence with the brand / product" on "customer's attitude toward brand". This can be explained as follows: everyday, customers can watch a lots of advertisements with celebrity, even the same one in different advertisements. When a brand / product is advertised by a celebrity with suitable image that is highly relevant to the brand / product, the confidence will be higher on the advertisement and the celebrity compared to a brand / product image promoted by a less famous, less relevant person.

\subsubsection{Customer's Attitude toward Brand}

This variable is statistically significant at $1 \%$, with value $\beta=0.696>0$, meaning that H'7 hypothesis is not supported. Customer's attitude toward brand is predisposition that focuses on favorable or unfavorable impact on a specific brand after watching an advertisement on that brand (Phelps \& Hoy, 1996). The study by Pham and Nguyen (2015) does not consider the effect of "customer's attitude toward brand" factor on the "purchase intention". Studies of Qurat and Mahira (2012), Aycha and Kaouther (2010) and Mazzini et al. (2014) indicate the positive effect of "customer's attitude toward brand" factor on the "purchase intention". Results of this study also affirm the correctness of previous studies. This impact is positive and considerable in Vietnamese market. Attitude is used as factor to forecast customer's intention and behavior (Fishbien \& Ajzen, 1975; Ajzen, 1991). When customers have more positive attitude toward brand, they will more likely intend to purchase the products.

\section{Conclusions and Recommendations}

\subsection{Conclusions}

The final study model includes 7 factors of celebrity endorsement with impact on customer's attitude toward brand. Also, factors of attitude toward brand have impacts on customer's purchase intention. After testing the reliability of the measurement scale and conducting explanatory factor analysis, results are that celebrity liking factor is eliminated while other factors are retained, resulting in a correction of study model hypotheses. Results of the multi-variable regression analysis indicate that customer's attitude toward brand in Vietnam is positively affected by 03 factors: celebrity match-up congruence with the brand / product, celebrity trustworthiness, and celebrity expertises. Results also indicate that purchase intention is strongly and positively impacted by customer's attitude toward brand.

\subsection{Suggestions of Policy Implications}

Based on findings, the study suggests some policy implications as follows:

Firstly, enterprises should pay careful attention to selecting celebrities for promoting the brand. If the celebrity 
has made any dispute statement, improper behavior, and a negative scandal, it will negatively affect the brand and reputation of the enterprises. Therefore, it is necessary to select a trustworthy celebrity that is trusted by the public.

Secondly, not every celebrity endorses a brand that is within his/her expertise. Therefore, customers usually wonder that celebrity endorsement is just intended to make the ads attractive, but product quality is not persuasive because it is beyond his/her expertise. Thus, if an enterprise luckily chooses a celebrity that is an expert in the brand that it wants to promote, the persuasiveness and customer's attitude toward brand will be more positively impacted.

Thirdly, when enterprises can formulate a meaningful message that is suitable to the celebrity and brand, this will have a positive impact on customer's attitude toward brand. So, enterprises need to select a suitable celebrity for their brand images and advertising message that they want to transfer, so that customers have better perception of the advertisements and positive attitude toward the brand.

\section{References}

Amos, C., Holmes, G., \& Strutton, D. (2008). Exploring The Relationship between Celebrity Endorser Effects and Advertising Effectiveness. A Quantitative Synthesis of Effect Size. International Journal of Advertising, 27(2), 209-234. http://dx.doi.org/10.1080/02650487.2008.11073052

Aycha, M. G., \& Kaouther, S. B. R. (2010). The Persuasive Effectiveness of Famous and Non Famous Endorsers in Advertising. IBIMA Business Review, 14. http://dx.doi.org/10.5171/2010.474771

Broostin, D. (1982). The Image: A Guide to Pseudo-Events in America. New York: Athenneum, 49.

Erdogan, B. Z. (1999). Celebrity endorsement: A literature review. Journal of Marketing Management, 14, 291-314. http://dx.doi.org/10.1362/026725799784870379

Freiden, J. B. (1984). Advertising Spokesperson Effects: An Examination of Endorser Type and Gender on Two Audiences. Journal of Advertising Research, 24(5), 33-41.

Friedman, H., Termini, S., \& Washington, R. (1976). The Effectiveness of Advertisements Utilizing Four Types of Endorsers. Journal of Advertising, 5(3), 22-24. http://dx.doi.org/10.1080/00913367.1976.10672647

Goldsmith, R., Lafferty, B., \& Newell, S. (2000). The Impact of Corporate Credibility and Celebrity Credibility on Consumer Reaction to Advertisements and Brands. Journal of Advertising, 29(3), 43-54. http://dx.doi.org/10.1080/00913367.2000.10673616

Gresham, L. G., \& Shimp, T. A. (1985). Attitude toward The Advertisement and Brand Attitudes: A Classical $\begin{array}{lllll}\text { Conditioning } \quad \text { Perspective. Journal of Advertising, } & \text { 14(1), }\end{array}$ http://dx.doi.org/10.1080/00913367.1985.10672924

Hoekman, M. L. L., \& Bosmans, A. M. M. (2010). Celebrity Endorsement. How Does Celebrity Endorsement Influence The Attitude towards The Brand and How Does Negative Publicity Affect This Relationship? Bachelor Thesis, ANR. 343396, Tilburg University, Netherlands.

Hovland, C. I., \& Weiss, W. (1953). The Influence of Source Credibility on Communication Effectiveness. Public Opinion Quarterly, 15, 635-650. http://dx.doi.org/10.1086/266350

Kaikati, J. G. (1987). Celebrity Advertising: A Review and Synthesis. International Journal of Advertising, (6), 99-105. http://dx.doi.org/10.1080/02650487.1987.11107007?src=recsys

Kamins, M. A., \& Gupta, K. (1994). Congruence between Spokesperson and Product Type: A Matchup Hypothesis Perspective. Psychology and Marketing, 11(6), 569-586. http://dx.doi.org/10.1002/mar.4220110605

Kotler, P., Keller, K., \& Jha, M. (2007). Marketing Management. A South Asian perspective (12th ed.). Pearson Education, 340.

Mazzini, M., Musa, R., Mohamed, R. N., \& Borhan, H. (2014). Celebrity Entrepreneur Endorsement and Advertising Effectiveness. Procedia - Social and Behavioral Sciences, 130, 11-20. http://dx.doi.org/10.1016/j.sbspro.2014.04.002

McCracken, G. (1989). Who Is The Celebrity Endorser? Cultural Foundation of The Endorsement Process. Journal of Consumer Research, 16, 310-321. http://dx.doi.org/10.1086/209217

McGuire, W. J. (1985). Attitudes and Attitude Change. In G. Lindzey, \& E. Aronson (Eds), Handbook of Social Psychology (Vol. 2, pp. 233-346). New York: Random House. 
Ohanian, R. (1990). Construction and Validation of A Scale to Measure Celebrity Endorsers' Perceived Expertise, Trustworthiness, and Attractiveness. Journal of Advertising, 19(3), 39-52. http://dx.doi.org/10.1080/00913367.1990.10673191

Ohanian, R. (1991). The Impact of Celebrity Spokesperson's Perceived Image on Consumers' Intention to Purchase. Journal of Advertising Research, 31(1), 46-52.

Pham, T. M. L., \& Nguyen, T. V. (2015). The Effect of Celebrity Endorsement in Advertising on Consumer Attitude. Journal of Economics and Development, (215), 76-86.

Phelps, J. E., \& Hoy, M. G. (1996). The Aad-Ab-PI Relationship in Children: The Impact of Brand Familiarity and Measurement Timing. Psychology and Marketing, 13(1), 77-101. http://dx.doi.org/10.1002/(SICI)1520-6793(199601)13:1<77::AID-MAR5>3.0.CO;2-M

Pornpitakpan, C. (2003). The Effect of Celebrity Endorsers' Perceived Credibility on Product Purchase Intention: The Case of Singaporeans. Journal of International Consumer Marketing, 16(2), 55-74. http://dx.doi.org/10.1300/J046v16n02_04

Qurat, U. A., \& Mahira, R. (2012). Impact of Celebrity Advertisement on Customers' Brand Perception and Purchase Intention. Asian Journal of Business and Management Sciences, 1(11), 53-67.

Shahrokh, Z. D., \& Arefi, A. (2013). Identify Factors Influencing on The Effectiveness of Celebrities Advertising. Journal of Applied Environmental and Biological Sciences, 3(12), 112-121.

\section{Copyrights}

Copyright for this article is retained by the author(s), with first publication rights granted to the journal.

This is an open-access article distributed under the terms and conditions of the Creative Commons Attribution license (http://creativecommons.org/licenses/by/4.0/). 